the sugar, which was initially less than $5 \mathrm{mg}$./100 $\mathrm{ml}$., rose to $72 \mathrm{mg}$./ $100 \mathrm{ml}$. Again no serious sideeffects were noted.

In spite of the apparent good initial response to
Penbritin, the patient subsequently died. At autopsy he was found to have a pocket of pus in his posterior fossa from which the organism was isolated.

\title{
REFERENCES
}

Brown, D. M., and ACred, P. (1961): 'Penbritin '-a New Broad Spectrum Antibiotic, Brit. med. F., ii, I97.

KNudSen, E. T., Rolinson, G. N., and STEvens, S. (1961): Absorption and Excretion of 'Penbritin', Ibid., ii, r 98, Rolinson, G. N., and Stevens, S. (196I): Microbiological Studies on a New Broad Spectrum Penicillin - 'Penbritin', Ibid., ii, $19 \mathrm{r}$.

SeabuRY, J. H., and Dascomb, H. E. (1958): Experience with Amphotericin B for the Treatment of Systemic Mycoses. Arch. intern. Med., 102, 960.

Stewart, G. T., Coles, H. M. T., Nixon, H. H., and Holt, R. J. (196r): ' Penbritin': An Oral Penicillin with Broad Spectrum Activity, Brit. med. F., ii, 200.

\section{PERNICIOUS ANAEMIA IN A YOUNG ADULT}

\author{
Sidney SHAw, M.D.(LoND.) \\ Reader in Hamatology and Consultant Hamatologist
}

J. G. Lewis, M.D.(LoND.), M.R.C.P. Senior Medical Registrar

Charing Cross Hospital and Medical School, London, W.C.2

Pernicious an emia is rare in young adults. Davis (1944) reviewed six large series of patients diagnosed as pernicious anæmia and, out of a total of 1,532 , only four were below the age of 20 years; the inadequacy of data necessary for a diagnosis of Addisonian anæmia in most of the cases previously described in young patients was noted. Wilkinson (1949) found an incidence of $2.8 \%$ of patients less than 30 years of age among 1,600 when first diagnosed; only one patient was under 21 years, and $67 \%$ were over the age of 50 years. Davidson (1952) in his Edinburgh series of 135 patients (1944-48) recorded $42 \%$ between the ages of 60 and 80 years when diagnosed. He later (1957) gave an incidence of over $50 \%$ occurring over 60 years of age in 100 cases (1950-56). Lambert, Prankerd and Smellie (196I) reviewed earlier publications on pernicious anæmia in childhood. They considered malabsorption of importance in the differential diagnosis and observed that fat-balance tests had been carried out in very few cases; the demonstration of intrinsic-factor deficiency is essential for the true diagnosis of pernicious anæmia, and they noted that in previous reports this examination had very rarely been carried out; in only four cases amongst those previously recorded was there adequate evidence of absence of intrinsic factor together with a satisfactory response to antipernicious anæmia therapy. They reported three recent cases diagnosed by modern techniques using labelled vitamin $\mathbf{B}_{12}$. The authors similarly investigated two further cases of juvenile pernicious anæmia in siblings, and referred to a further similar report on two siblings by Leikin (r960).
Recently, Metz, Randall and Kniep (I96r) described three cases of pernicious anæmia in young Bantu females.

Owing to the rarity of this condition in the young and the importance of precise diagnosis it was considered worthwhile to record the following case; according to our records this is the first such case below the age of 25 years to be admitted to this hospital during the last 14 years.

\section{Case Report}

N.M., an unmarried Irish woman aged 24 years, was admitted to this hospital in December I960 with weakness of the legs and difflculty in walking. She had been a barmaid until one year before; her alcoholic intake had been 'several shorts on two or three nights a week' and she usually smoked 20 to 30 cigarettes a day. Her father died at 42 years of age of diabetes mellitus and a paternal aunt also had diabetes mellitus. There was no family history of anæmia.

During the last year she had noticed shortness of breath on exertion with slight swelling of the ankles in the evenings; there was also a cough with a little yellow sputum. Her appetite was poor, there was no indigestion but she complained of increased thirst.

Three months before admission she saw her doctor with backache and painful frequent micturition; this was treated firstly with sulphonamides and finally responded fully to injections of streptomycin for 12 days.

One month before she had gone to bed with ' $\mathrm{flu}$ '; she had pyrexia, backache and aching all over. There was no further frequency of micturition but she thought her urine was cloudy and 'chocolate' coloured, and this appearance gradually cleared after about two weeks. One week after being in bed she stated that she suddenly became numb from the waist downwards and could not walk properly - she fell twice and felt as though 


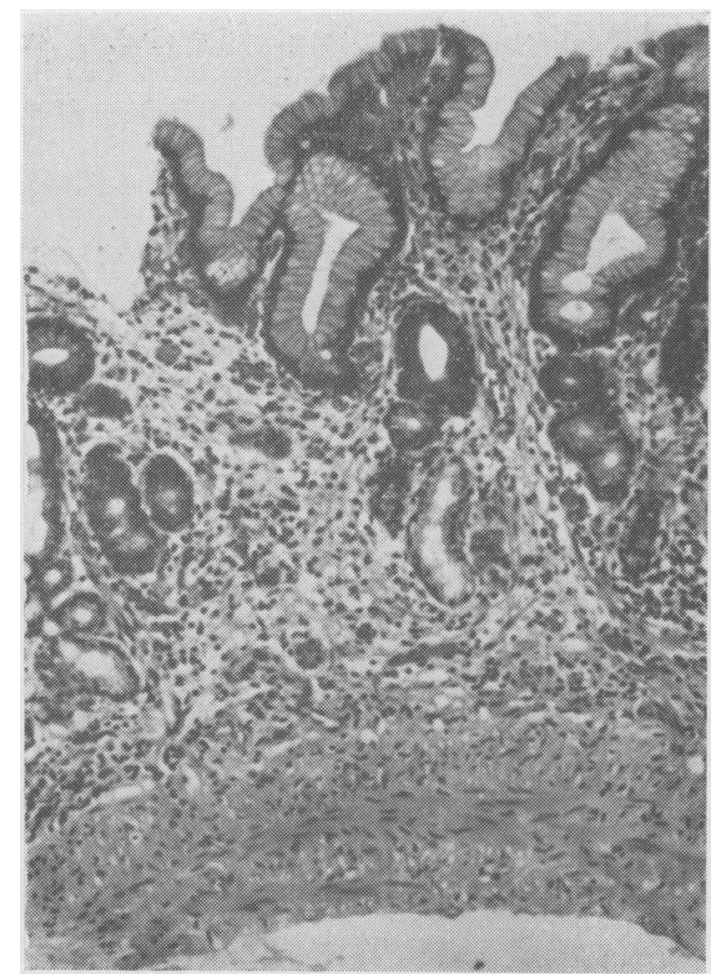

FIG. I.-Gastric biopsy showing characteristic atrophy.

drunk. Both legs felt weak especially the left, her finger-tips felt numb and she found difficulty in holding objects.

During the last few months her weight had fallen by I $5 \mathrm{lb}$. to $87 \mathrm{lb}$.

Examination revealed an ill, rather pale girl with dyed hair. The mucous membranes showed slight pallor and the tongue appeared normal.

She seemed mentally depressed but was co-operative. The cranial nerves were normal. The limbs were generally wasted and hypotonic; there was marked ataxia, especially in the legs. Power was reduced, especially in the legs, and there was left foot drop. The limb and abdominal reflexes were absent and the plantar responses were flexor. Her calves were tender on pressure; vibration sense was absent in the hands and below the knees; sensation to pin prick and cotton wool were diminished at the same sites. The Romberg test was positive. The cardiovascular, respiratory and alimentary systems were normal.

Investigations. Blood examination showed a slight macrocytic anæmia. Hb. 10.2 g./ $100 \mathrm{ml}$. (69\%); r.b.c., 3,160,000/c.mm.; colour index, I.0; average mean cell diameter (halömeter), $7.7 \mu$; P.C.V., $33 \%$; M.C.H.C., $31 \%$; M.C.V., 97 c. $\mu$; the red cells showed marked anisocytosis, moderate polychromasia and slight poikilocytosis; occasional cells were macrocytic. W.b.c., 6,700/c.mm. (neutrophils $53 \%$, eosinophils $2 \%$, basophils $1 \%$, monocytes $4 \%$, lymphocytes $40 \%$ ). Platelets, $267,000 /$ c.mm.; reticulocytes $4 \%$.

Sternal marrow aspiration showed a normal incidence of total nucleated cells; erythropoiesis was active and partially megaloblastic, hæmoglobination of the nucleated red cells was normal; granulopoiesis and platelet formation appeared normal. The serum vitamin $B_{12}$ level was $24 \mu \mu \mathrm{g} . / \mathrm{ml}$. (Lactobacillus leichmannii method); thi was abnormally low. The gastric juice showed no free acid by the standard histamine test meal and also bs the augmented histamine test meal (0.04 mg. histamine $\mathbb{Z}$ $\mathrm{kg}$. with $100 \mathrm{mg}$. anthisan i.m. 40 minutes before) The Schilling test using ${ }^{58} \mathrm{Co}$ showed $1 \%$ excretion of: the administered radioactive vitamin $B_{12}$, and this rose to $12 \%$ in a subsequent test repeated with $40 \mathrm{mg}^{-}$ intrinsic factor. Total fæcal fat was $22 \%$ of the dro weight of the stools and $80 \%$ was split; a three-da collection of fæces contained $9 \mathrm{~g}$. of fat; 13 . I labelled triolein uptake from the gut was normal as reflected byD normal fæcal activity and peak blood levels. A bariun? meal flowed normally through the small bowel, an there was no evidence of diverticula or flocculation of the barium. A jejunal biopsy was considered within normal limits.

Repeated tests showed no evidence of porphyrinuriaç there was slight proteinuria with the presence of scants red cells and a few pus cells; $B$. coli and Strep. facalio were grown.

Normal results were obtained in the glucose tolerancei and liver function tests, the blood and cerebrospina甲 fluid Wassermann reactions, and chemistry and cytolog $\mathbb{W}$ of the cerebrospinal fluid.

A chest radiograph appeared normal.

Course. There was an excellent clinical and hæmato logical response to intramuscular vitamin $B_{12}$ therapy reticulocytes reached $10 \%$ on the eighth day and by two months her hæmoglobin level rose to $15.5 \mathrm{~g} . \dot{L}$ $100 \mathrm{ml}$. (105\%). With intensive physiotherapy walkin rapidly improved, and four months after therapy com menced she could walk and dance in high-heeled shoes? and the sensation had returned to her legs.

\section{Discussion}

The outstanding clinical feature on admiss was that of a neurological disturbance, and the signs were predominantly those of a severe polyo neuritis accompanied by evidence of posteriof column involvement with no indication of affection of the lateral columns.

The initial history suggested the possibilities $0 \overrightarrow{\overrightarrow{\hat{\Phi}}}$ porphyrinuria, diabetes mellitus or alcoholism, but subsequent detailed investigations showed her tơ̆ have the characteristic features of Addisonian. anæmia. The family history of diabetes mellitus is of interest since a close familial association has.. been recorded by Joslin, Root, White and Marblè ( 1959 ), who noted that in 1,500 consecutive cases. of diabetes, pernicious anæmia was present is a parent or sibling in 15 instances.

Of the few cases in childhood and young adults in the past diagnosed as pernicious anæmia it is likely that most were true megaloblastic anæmias but few were true Addisonian anæmias.

In young patients with megaloblastic anæmia if is essential to rule out malabsorption as the cause. In a leading article (Lancet, 196I), it is stated that "the commonest cause of megaloblastic anæmi in childhood is overt or latent steatorrhœa'. Fat absorption tests in our patient were normal and further confirmation was obtained by the ${ }^{131} \mathrm{~F}$ labelled triolein uptake. Barium meal follows through and a jejunal biopsy were also normal.

The exact diagnosis is of considerable importanc as such patients, in accordance with our existing $5^{+}$ knowledge, will need lifelong substitutional therapy 
Recent investigations have added to our means of establishing the true diagnosis of pernicious anæmia. Until recently the cardinal laboratory features in pernicious anæmia were the characteristic blood picture, megaloblastic marrow and histaminefast achlorhydria.

The serum vitamin $B_{12}$ level in our patient was abnormally low; this estimation may bring to light examples of neurological disease due to vitamin $B_{12}$ deficiency: this is amplified by the clinical picture resembling that of the patients reported by Jewesbury (1954).

Absolute achlorhydria was confirmed by the augmented histamine test meal, and the most important feature, absence of intrinsic factor production, was confirmed by the Schilling test carried out before and after giving the patient intrinsic factor.
The patient responded fully to vitamin $B_{12}$ therapy.

\section{Summary}

Pernicious anæmia is recorded in a patient aged 24 years, presenting chiefly with neurological manifestations.

The rarity of this disease in young patients is pointed out and reference is made to the literature. The importance of precise diagnosis aided by newer techniques is stressed owing to the necessary lifelong substitution therapy required.

We would like to thank Dr. P. B. S. Fowler for his co-operation and allowing us to study his patient; Dr. R. A. Parkins, who performed the intestinal biopsy; and Dr. A. Jacobs, who did the gastric biopsy.

\title{
REFERENCES
}

Davidson, L. S. P. (1952): Thirty Years' Experience of Megaloblastic Anæmias, Edinb. med. Y., 59, 315.

Davidson, S. (1957): Clinical Picture of Pernicious Anæmia Prior to Introduction of Liver Therapy in 1926 and in Edinburgh Subsequent to 1944, Brit. med. $\mathcal{Y}$., i, 24I.

Davis, L. J. (1944): Macrocytic Anæmia in Children, with Report of Three Cases Showing Megaloblastic Erythropoiesis, Arch. Dis. Childh., 19, 147.

JewesburY, E. C. O. (1954): Subacute Combined Degeneration of the Cord and Achlorhydric Peripheral Neuropathies Without Anæmia, Lancet, ii, 307.

Josuin, E. P., Root, H. F., White, P., and Marble, A. (1959): 'The Treatment of Diabetes Mellitus', roth ed. London: Kimpton.

Lambert, H. P., Prankerd, T. A. J., and Smellie, J. M. (196r): Pernicious Anæmia in Childhood: a Report of Two Cases in One Family and Their Relationship to the Ætiology of Pernicious Anæmia, Quart. F. Med., 30, 7r.

Lancet (1961): Leading article, i, 984 .

LeIKIN, S. L. (I960): Pernicious Anæmia in Childhood, Pediatrics, 25, 9r.

Metz, J., RANDALL, T. W., and KNIEP, C. H. (1961): Addisonian Pernicious Anæmia in Young Bantu Females, Brit. med. $\mathcal{F}$., i, 178 .

Wilkinson, J. F. (1949): Megalocytic Anæmias, Lancet, i, 336.

\section{HYPERTROPHIC PULMONARY OSTEOARTHROPATHY ASSOCIATED WITH PULMONARY METASTASES REMOVED SURGICALLY}

\author{
C. P. Alexander, M.B., M.R.C.P. \\ Senior Medical Registrar \\ V. W. Johnson, M.B., Cн.B. \\ formerly Medical Registrar*
}

Royal Hospital, Sheffield

\begin{abstract}
Clubbing of the fingers and toes of the most advanced type, associated with thickening of the bones of the carpus and tarsus, painful swollen joints, and with periosteal thickening of the long bones of the limbs, is a well-recognized complication of many chest diseases. This degree of clubbing or, as it is more usually called, hypertrophic pulmonary osteoarthropathy (H.P.O.A.), is found most commonly in cases of bronchial car-
\end{abstract}

\footnotetext{
* Prosent addrers, Redhill County Hospital, Surrey.
}

cinoma, where the incidence in a large series was up to $2 \%$ (Semple and McCluskie, r955). H.P.O.A. has also been observed in association with pulmonary metastases of many kinds arising from primary neoplasms outside the chest. Metastases in the lungs arising from primary osteogenic sarcomata are more often accompanied by the development of H.P.O.A. than is spread from other non-pulmonary primaries (Mendlowitz, 1942; Gibbs, Schiller and Stovin, 1960).

The case to be described is that of a young girl 